\title{
A new species of the freshwater crab genus Potamonemus Cumberlidge \& Clark, 1992 (Crustacea, Potamonautidae) endemic to the forested highlands of southwestern Cameroon, Central Africa
}

\author{
Pierre A. Mvogo Ndongo ${ }^{1,2}$, Thomas von Rintelen ${ }^{2}$, Neil Cumberlidge ${ }^{3}$
}

I Département de Gestion des Écosystèmes Aquatiques, Institut des Sciences Halieutiques, Université de Douala à Yabassi, PO. Box. 7236, Douala-Bassa, Cameroun 2 Museum für Naturkunde, Leibniz Institute for Evolution and Biodiversity Science, Invalidenstraße 43, 10115, Berlin, Germany 3 Department of Biology, Northern Michigan University, Marquette, MI, 49855-5376, USA

Corresponding author: Pierre A. Mvogo Ndongo (mpierrearmand@yahoo.fr)

Academic editor: C. Magalhães | Received 21 November 2020 | Accepted 12 January 2021 | Published 15 February 2021

http://zoobank.org/36B25C08-43C8-4622-9189-B4F692651CFB

Citation: Mvogo Ndongo PA, von Rintelen T, Cumberlidge N (2021) A new species of the freshwater crab genus Potamonemus Cumberlidge \& Clark, 1992 (Crustacea, Potamonautidae) endemic to the forested highlands of southwestern Cameroon, Central Africa. ZooKeys 1017: 127-141. https://doi.org/10.3897/zookeys.1017.60990

\begin{abstract}
A new species of freshwater crab of the genus Potamonemus Cumberlidge \& Clark, 1992 is described from Mount Manengouba Reserve and Bakossi National Park in the tropical rainforests of southwestern Cameroon, Central Africa. Potamonemus man sp. nov. is recognized by characters of the carapace and chelipeds. In addition, a phylogenetic analysis based on partial sequences of three mitochondrial DNA genes (COI, 12S rRNA, and 16S rRNA) that included representatives of all other freshwater crab genera found in Cameroon recovered each of the new species as a distinct lineage. A diagnosis and illustrations of the new species are provided, and it is compared to the other species of Potamonemus. Brief notes are provided on the ecology of the new species and the two other species of Potamonemus. An identification key to the species of Potamonemus is provided. The conservation status of the genus is discussed.
\end{abstract}

\section{Keywords}

Afrotropical region, conservation, identification key, mtDNA, taxonomy

Copyright Pierre A. Mvogo Ndongo et al. This is an open access article distributed under the terms of the Creative Commons Attribution License (CC BY 4.0), which permits unrestricted use, distribution, and reproduction in any medium, provided the original author and source are credited. 


\section{Introduction}

Potamonemus Cumberlidge \& Clark, 1992 is one of five genera of freshwater crabs currently known from Cameroon. The other four species are Buea Cumberlidge, Mvogo Ndongo, Clark \& Daniels, 2019, Louisea Cumberlidge, 1994, Potamonautes MacLeay, 1838, and Sudanonautes Bott, 1955 (Cumberlidge 1987, 1989, 1993a, b, c, 1994a, b; 1999; Cumberlidge and Boyko 2001; Cumberlidge and Clark 1992; Cumberlidge et al. 2019; Mvogo Ndongo et al. 2017a, b, c, 2018, 2019, 2020). Potamonemus was originally established as a monotypic genus for $P$. mambilorum Cumberlidge \& Clark, 1992, and in the following year two more species were described, namely $P$. asylos Cumberlidge, 1993 and $P$. sachsi Cumberlidge, 1993. Subsequent phylogenetic analyses of the Afrotropical freshwater crab fauna (Daniels et al. 2006, 2015) supported the close relationship between $P$. mambilorum and $P$. sachsi but indicated that $P$. asylos formed a separate genetic lineage from these two species. Recently, $P$. asylos was assigned to a new genus, Buea Cumberlidge, Mvogo Ndongo, Clark \& Daniels, 2019. Mvogo Ndongo et al. (2020) recently described three additional Buea species, including B. bangem Mvogo Ndongo, von Rintelen, Tomedi-Tabi \& Cumberlidge, 2020, B. mundemba Mvogo Ndongo, von Rintelen \& Cumberlidge in Mvogo Ndongo, von Rintelen, Tomedi-Tabi and Cumberlidge 2020, and B. nlonako Mvogo Ndongo, von Rintelen \& Cumberlidge in Mvogo Ndongo, von Rintelen, Tomedi-Tabi and Cumberlidge 2020.

Cumberlidge et al. (2019) and Mvogo Ndongo et al. (2020) established that Buea is endemic to southwestern Cameroon and that Potamonemus is a more widely distributed genus, with a range including southwestern Cameroon and eastern Nigeria. Cumberlidge et al. (2019) revised the diagnostic characters of Potamonemus as a 2-segmented mandibular palp lacking a lobe or anterior flap at the junction between the two segments, a G1 with a slim, outward-curving and elongated TA (TA/SS 0.63) that lacks marginal setae and tapers to a pointed tip, and a G2 with a remarkably short TA (TA/SS 0.13). The three protected areas surveyed in the present study for freshwater decapods are located in a region of southwestern Cameroon which has been recognised as a biodiversity hotspot for several other freshwater taxa.

Extensive systematic surveys carried out from 2017 to 2020 in the lowland and upland zones of the tropical rainforests of southwestern Cameroon resulted in the collection of several new taxa, including a new species of Potamonemus. The purpose of the present study is to describe this new species using an integrative approach based on morphological characters and molecular genetic data and to provide a key to the three species now assigned to this genus. The molecular analysis based on three partial mitochondrial genes (COI, 12S rRNA, and 16S rRNA) also recovers the three species as separate genetic lineages within Potamonemus. For all the species treated in this study we also provide notes on their ecology and conservation. 


\section{Materials and methods}

\section{Sampling}

Field surveys of freshwater decapods were conducted in 2017 at Mount Manengouba Reserve and Bakossi National Park, and in 2018 and 2020 at Nlonako Ecological Reserve. Survey transects were made in each study area. Crabs were collected from small rivers using nylon fishnets and dip nets, and near small permanent streams where crabs were found in puddles, under fallen leaves, under stones, and in burrows. The amount of disturbance of the habitat and the various threats to freshwater organisms, including to freshwater crabs, were evaluated during structured discussions with local people.

\section{Morphological analyses}

All measurements (in $\mathrm{mm}$ ) were taken with digital callipers. The terminology used follows Cumberlidge (1999), and the classification follows Ng et al. (2008). Characters of the gonopods, carapace, thoracic sternum, chelipeds, third maxillipeds, and mandibles were examined in detail, and photographs were taken using a Leica microscope (model Z16A POA), LAS V4, and Helicon Focus 6.7.1 software. Post processing of the images was undertaken using Adobe Photoshop CC5 and Photo Impact. The newly collected specimens were deposited in the Museum für Naturkunde, Berlin, Germany (ZMB). Other material is deposited in the Institute of Fisheries and Aquatic Sciences, University of Douala at Yabassi (IFAS).

\section{Abbreviations used}

A pleonal (abdominal) segment or $\mathbf{G 1}$ male first gonopod; pleomere; $\quad$ G2 male second gonopod;

A5/A6 sulci between adjacent pleomeres; P2-5 pereiopods 2-5 or ambulatory

a.s.l. above sea level; legs 1-4;

CW carapace width measured at wid- SS subterminal segment of G1 or G2; est point;

S4/E4 (S4/E4, S5/E5, S6/E6, S7/E7)

CL carapace length measured along episternal sulci between adjacent medial line from anterior to posterior margin;

$\mathbf{S}$ thoracic sternite;

CH carapace height measured at maxi- S1/S2 mum height of cephalothorax;

E episternite;

(or S2/S3, S4/S5, S5/S6, S6/S7) sternal sulci between adjacent thoracic sternites;

FW front width measured along ante- TA terminal article of $\mathrm{G} 1$ or G2; rior frontal margin between inner TS angles of orbits; terminal segment of mandibular palp. 
Details for DNA extraction, DNA sequencing, PCR, and molecular phylogenetic analyses are given by Mvogo Ndongo et al. (2019, 2020). All sequences used in this study are given in Table 1.

\section{Systematic account}

Infraorder Brachyura Latreille, 1802

Superfamily Potamoidea Ortmann, 1896

Family Potamonautidae Bott, 1970

Subfamily Potamonautinae Bott, 1970

\section{Potamonemus man sp. nov.}

http://zoobank.org/58FD0C15-4CB9-4561-8453-B98255BBEE25

Figures 1d, 2d, 3d, 4d, 5g, h, 1, 6j-l, 7d, h

Common name: Man Lake freshwater crab

Holotype. Adult ô (CW $24.51 \mathrm{~mm}$, CL 17.09 mm, CH $9.62 \mathrm{~mm}$, FW $7.62 \mathrm{~mm}$ ), Cameroon, Southwest Region, Mount Manengouba Ecological Reserve, Man Lake, Mount Manengouba (5.02414, 9.82142), 1,958 m a.s.l., 14 March 2017, coll. P.A. Mvogo Ndongo (ZMB Crust. 30320).

Paratypes. 1 adult $\widehat{\delta}(\mathrm{CW} 21.37 \mathrm{~mm}, \mathrm{CL} 15.61 \mathrm{~mm}, \mathrm{CH} 8.45 \mathrm{~mm}, \mathrm{FW}$ $6.69 \mathrm{~mm}$ ), 1 adult + (CW $23.55 \mathrm{~mm}$, CL $16.87 \mathrm{~mm}, \mathrm{CH} 10.09 \mathrm{~mm}, \mathrm{FW} 7.60 \mathrm{~mm}$ ), Cameroon, Southwest Region, Mount Manengouba Ecological Reserve, Man Lake, Mount Manengouba (5.03604, 9.82906), 1,958 m a.s.l., 14 March 2017, coll. P.A. Mvogo Ndongo (ZMB Crust. 30324). 2 adult ô (CW $20.12 \mathrm{~mm}$, CL $14.64 \mathrm{~mm}$, CH 7.92 mm, FW 6.76 mm; CW 20.40 mm, CL 14.73 mm, CH 8.16 mm, FW $6.63 \mathrm{~mm}$ ); 3 subadult $\widehat{\jmath}$ (CW $18.46 \mathrm{~mm}$, CL $13.89 \mathrm{~mm}, \mathrm{CH} 7.40 \mathrm{~mm}, \mathrm{FW} 6.16 \mathrm{~mm}$; CW $19.38 \mathrm{~mm}$, CL $13.78 \mathrm{~mm}$, CH $7.78 \mathrm{~mm}$, FW $6.63 \mathrm{~mm}$; CW $14.05 \mathrm{~mm}$, CL $10.67 \mathrm{~mm}$, CH $5.84 \mathrm{~mm}$, FW $5.30 \mathrm{~mm}$ ), Cameroon, Southwest Region, Mount Manengouba Ecological Reserve, Man Lake, Mount Manengouba (5.03604, 9.82906), 1,958 m a.s.l., 14 March 2017, coll. P.A. Mvogo Ndongo (IFAS-017); 4 adult 9 (CW $19.39 \mathrm{~mm}$, CL $14.07 \mathrm{~mm}$, CH $7.74 \mathrm{~mm}$, FW $6.48 \mathrm{~mm}$; CW $17.37 \mathrm{~mm}$, CL $12.46 \mathrm{~mm}, \mathrm{CH} 6.94 \mathrm{~mm}, \mathrm{FW} 6.33 \mathrm{~mm}$; CW $16.88 \mathrm{~mm}$, CL $12.06 \mathrm{~mm}, \mathrm{CH}$ $6.36 \mathrm{~mm}$, FW $5.20 \mathrm{~mm}$ ), Cameroon, Mount Manengouba Ecological Reserve, Man Lake, Mount Manengouba (5.03604, 9.82906), 1,958 m a.s.l., 14 March 2017, coll. P.A. Mvogo Ndongo (IFAS-018).

Other material. Bakossi National Park (Figs 1c, 2c, 3c, 4c, 5e, f, j, 6g-i, 7c, g). 1 adult $\widehat{\partial}$ (CW $30.41 \mathrm{~mm}, \mathrm{CL} 20.57 \mathrm{~mm}, \mathrm{CH} 12.50 \mathrm{~mm}, \mathrm{FW} 9.32 \mathrm{~mm}$ ), 1 adult $q$ (CW $27.48 \mathrm{~mm}$, CL $20.06 \mathrm{~mm}, \mathrm{CH} 11.31 \mathrm{~mm}$, FW $8.19 \mathrm{~mm}$ ), Cameroon, Southwest Region, Bakossi National Park (5.031083, 9.687528), 1,253 m a.s.l., 15 March 2017, coll.

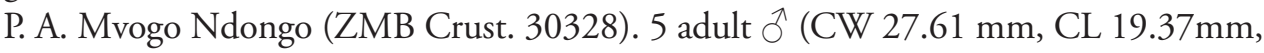
CH 11.39 mm, FW 8.65 mm; CW 26.54 mm, CL 19.09 mm, CH $10.80 \mathrm{~mm}$, FW $9.13 \mathrm{~mm}$; CW $25.55 \mathrm{~mm}$, CL $18.68 \mathrm{~mm}$, CH $10.58 \mathrm{~mm}$, FW $8.41 \mathrm{~mm}$; CW $25.3 \mathrm{~mm}$, 
Table I. Species and specimens of Louisea, Buea, Potamonemus, Sudanonautes, and Potamonautes and the outgroup taxa included in the molecular analysis. All measurements in $\mathrm{mm}$.

\begin{tabular}{|c|c|c|c|c|c|c|}
\hline \multirow[t]{2}{*}{ Species } & \multirow[t]{2}{*}{ Locality } & \multirow[t]{2}{*}{ Museum number } & \multirow[t]{2}{*}{ Reference study } & \multicolumn{3}{|c|}{ GenBank accession number } \\
\hline & & & & CO1 & 12S rRNA & 16S rRNA \\
\hline $\begin{array}{l}\text { Louisea nkongsamba } \\
\text { (CW 20.0) }\end{array}$ & Mt. Nlonako & ZMB Crust. 31618 & $\begin{array}{l}\text { Mvogo Ndongo } \\
\text { et al. } 2019\end{array}$ & MN188072 & MN217386 & MN217393 \\
\hline Louisea balssi (CW 14.8) & Manengouba & ZMB Crust. 29628 & $\begin{array}{l}\text { Mvogo Ndongo } \\
\text { et al. } 2019\end{array}$ & MN188070 & MN217384 & MN217391 \\
\hline Louisea edeaensis (CW 17.2) & Lake Ossa & LZUY 15-3 (T351-30) & $\begin{array}{l}\text { Mvogo Ndongo } \\
\text { et al. 2017c }\end{array}$ & KY964474 & KY964479 & KY964472 \\
\hline Buea mundemba. (CW 26.2) & Korup N. P. & ZMB Crust. 30321 & $\begin{array}{l}\text { Mvogo Ndongo } \\
\text { et al. } 2019\end{array}$ & MN188069 & MN217388 & MN217396 \\
\hline Buea bangem (CW 26.5) & Bakossi N.P. & IFAS-010 & $\begin{array}{l}\text { Mvogo Ndongo } \\
\text { et al. } 2020\end{array}$ & MT019691 & MT021447 & - \\
\hline Buea asylos (CW 25.4) & Buea and Kumba & NHM 1994.588-591 & Daniels et al. 2015 & KP640489 & KP640410 & KP640453 \\
\hline Potamonemus man sp. nov & Bakossi N. P. & ZMB Crust. 30328 & $\begin{array}{l}\text { Mvogo Ndongo } \\
\text { et al. } 2019\end{array}$ & MN188067 & MN217390 & MN217398 \\
\hline Potamonemus man sp. nov & $\begin{array}{l}\text { Mt. Manengouba } \\
\text { R. }\end{array}$ & ZMB Crust. 30320 & Present study & $\begin{array}{c}\text { GenBank } \\
\text { (submitted } \\
\text { by the } \\
\text { first author) }\end{array}$ & - & - \\
\hline Potamonemus mambilorum & $\begin{array}{l}\text { Southwest } \\
\text { Cameroon }\end{array}$ & NHM 1991.183 & Daniels et al. 2015 & - & KP640409 & KP640452 \\
\hline Potamonemus sachsi & $\begin{array}{l}\text { Southwest } \\
\text { Cameroon }\end{array}$ & NMU09.04.1983 & Daniels et al. 2015 & - & AY803490 & AY803530 \\
\hline Potamonautes idjiwiensis & D. R. Congo & SAM A78437 & Daniels et al. 2015 & KP640481 & KP640402 & KP640446 \\
\hline Potamonautes obesus & Tanzania & Unaccessioned & Daniels et al. 2015 & AY803647 & AY803497 & AY803537 \\
\hline Afrithelphusa monodosa & Guinea & NMU 25.IV.2005.C & Daniels et al. 2015 & KP640469 & KP640386 & KP640430 \\
\hline Globonautes macropus & Liberia & NMU VII. 1988 & Daniels et al. 2015 & - & KP640391 & KP640435 \\
\hline Sudanonautes aubryi & Cameroon & LZUY-06 & $\begin{array}{l}\text { Mvogo Ndongo } \\
\text { et al. 2017c }\end{array}$ & KY069938 & KY964475 & KY069950 \\
\hline Sudanonautes tiko & Cameroon & ZMB Crust.29628 & $\begin{array}{l}\text { Mvogo Ndongo } \\
\text { et al. 2017c }\end{array}$ & KY069941 & KY964476 & KY069954 \\
\hline
\end{tabular}

LZUY: Zoological Collection of the Laboratory of Zoology, University of Yaounde 1, Cameroon; NHM: Natural History Museum, London, UK; NMU: Northern Michigan University Museum, USA; NP, National park; ZMB: Museum für Naturkunde, Berlin, Germany.

CL $18.05 \mathrm{~mm}$, CH 10.70, FW $8.41 \mathrm{~mm}$ ) (IFAS-014); 2 subadult $\widehat{\jmath}$ (CW $22.17 \mathrm{~mm}$, CL $15.76 \mathrm{~mm}, \mathrm{CH} 9.04 \mathrm{~mm}$, FW $7.35 \mathrm{~mm}$; CW $22.02 \mathrm{~mm}$, CL $15.67 \mathrm{~mm}, \mathrm{CH}$ 9.06 mm, FW 7.49 mm; CW 22.04 mm, CL 16.00 mm, CH 9.22 mm, FW 7.65 mm; CW 21.35 mm, CL 15.19 mm, CH 8.76 mm, FW $6.81 \mathrm{~mm}$ ), Cameroon, Southwest Region, Bakossi National Park (5.031083, 9.687528), 1,248 m a.s.l., 15 March 2017, coll. P.A. Mvogo Ndongo (IFAS-015). 2 subadult + (CW $23.76 \mathrm{~mm}$, CL $17.57 \mathrm{~mm}$, CH 9.88 mm, FW 7.68 mm; CW 23.31 mm, CL 16.63 mm, CH 9.08 mm, FW $7.59 \mathrm{~mm})$, Cameroon, Southwest Region, Bakossi National Park (05.031083, 9.687528), 1,248 m a.s.l., 15 March 2017, coll. P.A. Mvogo Ndongo (IFAS-016).

Diagnosis. Carapace anterior surface smooth except for faint urogastric groove (Fig. 1d). Broad epimeral (longitudinal) suture on carapace sidewall (branchiostegite) dividing carapace sidewall into 2 regions, vertical (pleural) groove lacking (Fig. 1d). Outer lower margin of cheliped merus lined by small, blunt teeth, inner lower margin smooth, distal meral tooth distinct, pointed (Fig. 3d). Major chela dactylus straight (not arched) (Fig. 5g). Sternal sulcus S2/S3 completely traversing sternum; S3/S4 incomplete, reduced to 2 short, distinct notches on each side of sternum (Fig. 3d). G1 


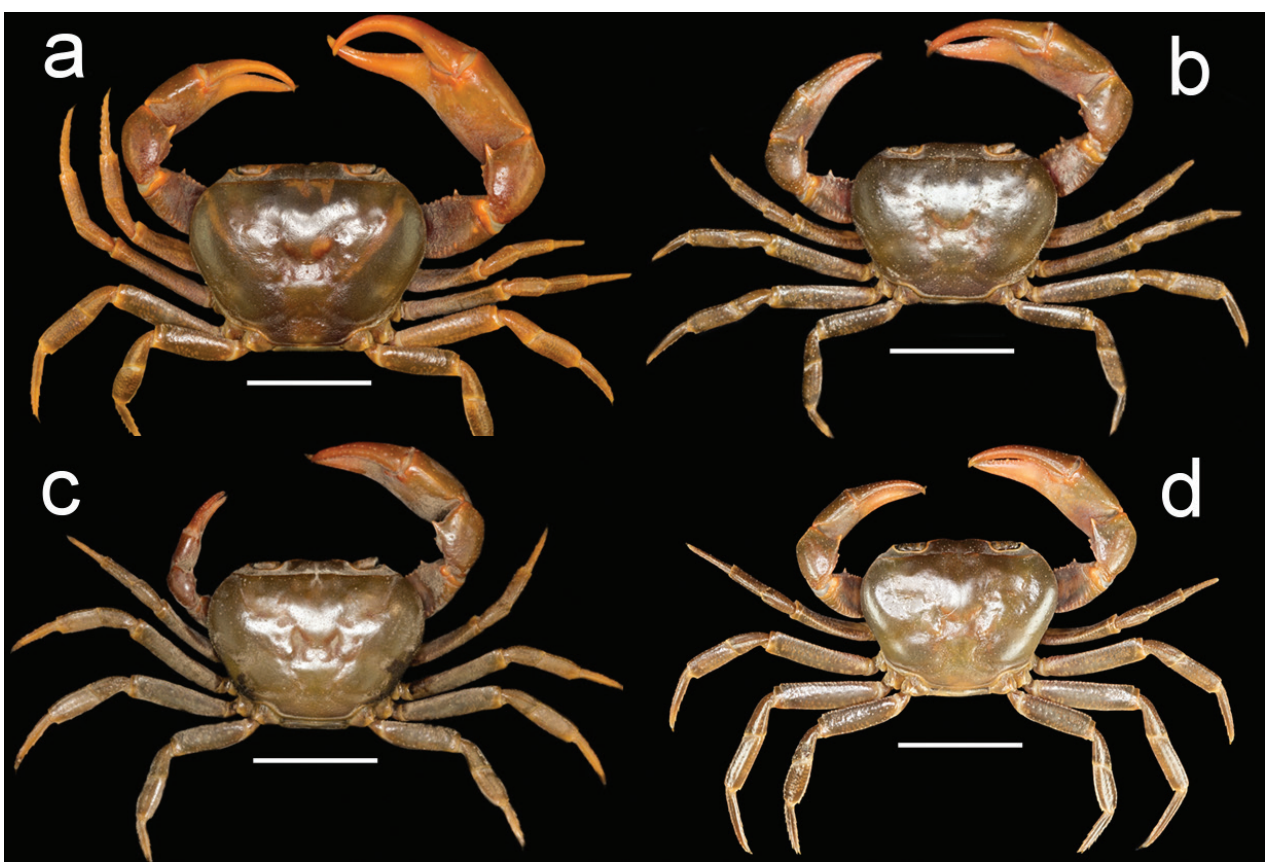

Figure I. Species of Potamonemus from southwestern Cameroon, whole animal, dorsal view a largest adult male (CW $29 \mathrm{~mm}$ ) of P. mambilorum from Mount Nlonako (ZMB Crust. 32428) b adult male (CW $28 \mathrm{~mm}$ ) of P. mambilorum from small stream on Mount Manengouba (ZMB Crust. 30326) c adult male (CW $31 \mathrm{~mm}$ ) of $P$. man sp. nov. from Bakossi National Park (ZMB Crust. 30328) d adult male, holotype (CW $25 \mathrm{~mm}$ ) of $P$. man sp. nov. from Man Lake, Mount Manengouba (ZMB Crust. 30320). Scale bars: $15 \mathrm{~mm}(\mathbf{a}), 16 \mathrm{~mm}(\mathbf{b}), 17 \mathrm{~mm}(\mathbf{c}), 16 \mathrm{~mm}(\mathbf{d})$.

with long TA (TA/SS 0.66), slim, curving outward, lacking marginal setae, tapering to pointed tip; G2 TA remarkably short (TA/SS 0.13) (Fig. 6j, l). A small species, mature between CWs 20-25 mm.

Description. Carapace ovoid, medium height $(\mathrm{CH} / \mathrm{FW} 1.17)$, wide $(\mathrm{CW} / \mathrm{FW}$ 3.19); carapace surface smooth; postfrontal crest distinct, completely traversing carapace, lateral ends meeting anterolateral margins (Fig. 1d); exorbital tooth low, distinct; intermediate, epibranchial teeth each reduced to small granule (Fig. 4d); anterolateral margin behind epibranchial tooth smooth (Fig. 4d). Carapace branchiostegite with prominent epimeral suture dividing wall into subhepatic/suborbital, pterygostomial regions; vertical (pleural) suture faint (Fig. 3d). Sternal sulcus S2/S3 deep, completely traversing sternum; S3/S4 incomplete, reduced to 2 short, distinct notches on each side of sternum (Fig. 3d); margins of S3, S4 raised, broad (Fig. 3d); episternal sulci S4/E4, S5/E5, S6/E6 faint or missing, S7/E7 complete (Fig. 3d). Mandibular palp 2-segmented; medium-sized anterior lobe at junction between segment $(0.25 \times \mathrm{TS}$ length; Fig. 7h). Third maxillipeds filling entire buccal cavern, except for transversely oval, efferent respiratory openings in superior lateral corners; ischium smooth, lacking vertical groove; exopod lacking flagellum (Fig. 7d). 

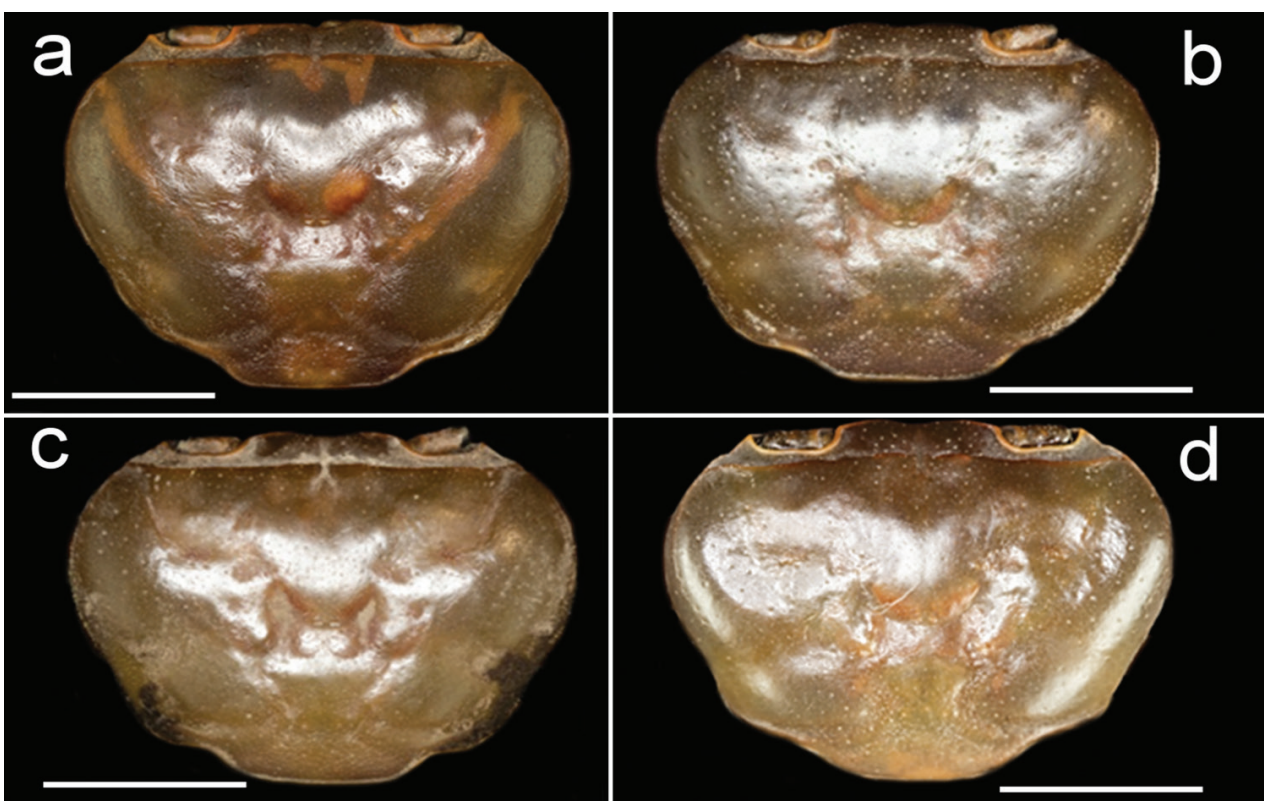

Figure 2. Species of Potamonemus from southwestern Cameroon, dorsal view a largest adult male (CW $29 \mathrm{~mm}$ ) of $P$. mambilorum from Mount Nlonako (ZMB Crust. 32428) b adult male (CW $28 \mathrm{~mm}$ ) of $P$. mambilorum from small stream on Mount Manengouba (ZMB Crust. 30326) c adult male (CW $31 \mathrm{~mm}$ ) of P. man sp. nov. from Bakossi National Park (ZMB Crust. 30328) d adult male, holotype (CW $25 \mathrm{~mm}$ ) of P. man sp. nov. from Man Lake, Mount Manengouba (ZMB Crust. 30320). Scale bars: 13 mm (a), $13 \mathrm{~mm}(\mathbf{b}), 14 \mathrm{~mm}(\mathbf{c}), 11 \mathrm{~mm}(\mathbf{d})$.

Male chelipeds greatly unequal, right cheliped larger than left (Figs 1d, 5g, h). Movable finger (dactylus), fixed finger (pollex of propodus) of right (major) chela both slim, elongated; fixed finger with 3 large pointed teeth ( 2 proximal, 1 distal); movable finger relatively stout, straight (not highly arched), with 4 small but distinct teeth (2 proximal, 2 distal; Fig. 5g). Left (minor) chela dactylus, propodus smaller than right chela, with small teeth on occluding margins (Fig. 5h). Inner inferior margin of cheliped merus lined by small teeth, outer inferior margin smooth; distal meral tooth large, pointed (Fig. 5d). Cheliped carpus inner margin with large pointed distal tooth; proximal tooth much smaller, followed by granule (Fig. 51). Ambulatory legs (P2-5) slender, P4 longest, P5 shortest; dactyli P2-5 tapering to point, each bearing rows of downward-pointing sharp bristles, P5 dactylus shortest (Fig. 1d).

Male pleon triangular, margins not indented and lacking setae (Fig. 3d). G1 with long TA (TA/SS 0.66), slim, curving outward, lacking marginal setae, tapering to pointed tip; G2 TA remarkably short (TA/SS 0.13) (Fig. 6j, l); G1 SS, broad in basal, midsection, distal quarter tapering sharply, narrow at junction with G1 TA (Fig. 6j, l). G2 TA extremely short (G2 TA/SS 0.3; Fig. 6k).

Adult female. Right and left chelipeds subequal. Fixed, movable fingers of chela interspersed with series of smaller acute teeth along their length. Pleon wide, covering 


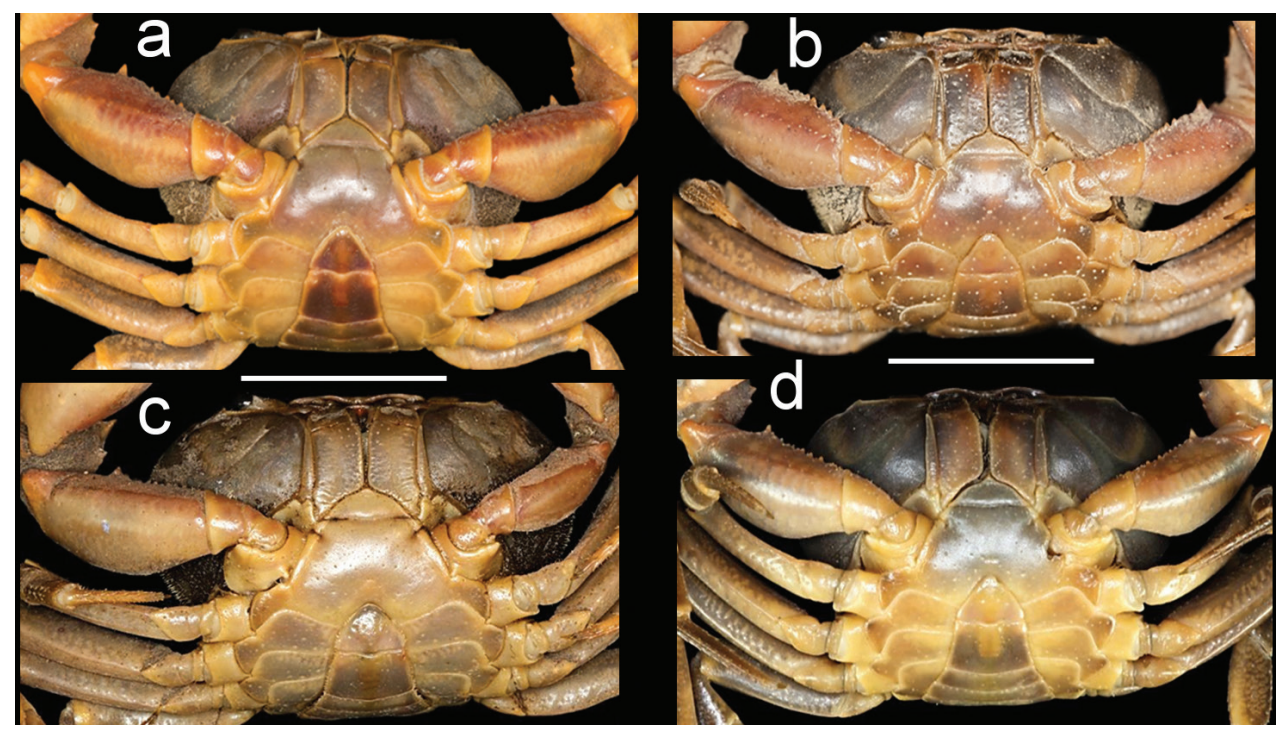

Figure 3. Species of Potamonemus from southwestern Cameroon, ventral view a largest adult male (CW $29 \mathrm{~mm}$ ) of P. mambilorum from Mount Nlonako (ZMB Crust. 32428) b adult male, holotype (CW $28 \mathrm{~mm}$ ) of $P$. mambilorum from small stream on Mount Manengouba (ZMB Crust. 30326) c adult male (CW $31 \mathrm{~mm}$ ) of P. man sp. nov. from Bakossi National Park (ZMB Crust. 30328) d adult male, holotype (CW $25 \mathrm{~mm}$ ) of $P$. man sp. nov. from Man Lake, Mount Manengouba (ZMB Crust. 30320). Scale bars: $16 \mathrm{~mm}(\mathbf{a}), 17 \mathrm{~mm}(\mathbf{b}), 16 \mathrm{~mm}(\mathbf{c}), 17 \mathrm{~mm}(\mathbf{d})$.

entire sternum, reaching bases of coxae of P2-5; pleon with 6 free pleomeres (A1-6) becoming gradually wider proximally, telson wide, forming near semicircle.

Size. Small species, CW in mature individuals ranging from $20.0-30.4 \mathrm{~mm}$.

Colour in life. Dorsal carapace and all ambulatory legs dark brown, chelipeds red.

Type locality. Stream flowing into Man Lake, Mount Manengouba, in Manengouba Ecological Reserve, Southwest Region of Cameroon.

Etymology. The species is named for Man Lake, one of a pair of small lakes in the caldera at the summit of Mount Manengouba (the other lake being Woman Lake). The species epithet is used as a noun in apposition.

Habitat. At the Man Lake locality at the summit of Mount Manengouba the species is found in a small stream flowing into the lake, and it was also collected from a small stream in the Bakossi National Park. Both of these localities are located in rainforest habitat found along the Cameroon Volcanic Line, a 1,600 km long chain of volcanoes that stretches from the islands in the Gulf of Guinea to the mountains of eastern Nigeria and western Cameroon, including Mount Cameroon.

Remarks. The new species is assigned to Potamonemus because it conforms to the genus diagnosis (Cumberlidge and Clark 1992; Cumberlidge 1993c; Cumberlidge et al. 2019). Potamonemus man sp. nov. most closely resembles $P$. sachsi in that the dactylus of the major cheliped of both species is straight rather than highly arched. These two species can be distinguished from each other by the smooth carapace and bran- 


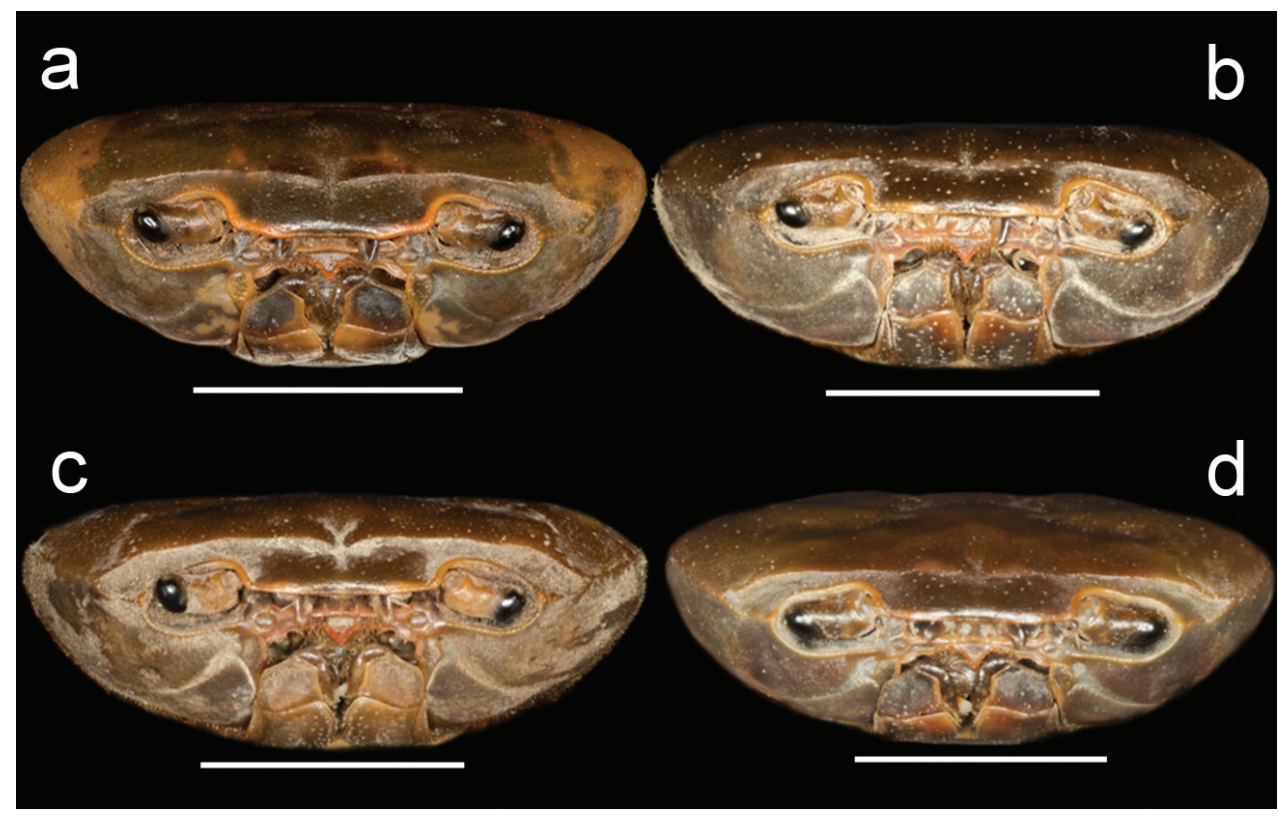

Figure 4. Species of Potamonemus from southwestern Cameroon, frontal view a largest adult male (CW $29 \mathrm{~mm}$ ) of P. mambilorum from Mount Nlonako (ZMB Crust. 32428) b adult male, holotype (CW $28 \mathrm{~mm}$ ) of $P$. mambilorum from small stream on Mount Manengouba (ZMB Crust. 30326) c adult male (CW $31 \mathrm{~mm}$ ) of $P$. man sp. nov. from Bakossi National Park (ZMB Crust. 30328) d adult male, holotype (CW $25 \mathrm{~mm}$ ) of P. man sp. nov. from Man Lake, Mount Manengouba (ZMB Crust. 30320). Scale bars: $13 \mathrm{~mm}(\mathbf{a}), 12 \mathrm{~mm}(\mathbf{b}), 14 \mathrm{~mm}(\mathbf{c}), 11 \mathrm{~mm}(\mathbf{d})$.

chiostegal sidewalls in $P$. man sp. nov. (Figs 1D, 2D) (vs. patches of short setae along the anterolateral and posterolateral margins of the carapace that continue around to the sidewalls in the subhepatic and pterygostomial regions of the branchiostegite in P. sachsi (Cumberlidge et al. 2019: fig. 4c)). The highly arched dactylus of the major cheliped of $P$. mambilorum distinguishes it from both $P$. man sp. nov. and $P$. sachsi. Finally, $P$. man sp. nov. can be distinguished from $P$. mambilorum and $P$. sachsi by the body size of adult specimens: the new species and $P$. sachsi are adult between CW 20-30 mm and CW $23-28 \mathrm{~mm}$, respectively, while P. mambilorum is the largest species (adult at CW 29-38 mm).

A phylogenetic tree (Fig. 8), based on 1,848 base pairs representing the combined partial sequences of three mtDNA markers (COI, 16S RNA, and 12S RNA), recovered three species of Potamonemus as a single clade with strong BI and ML confidence values (1/100 at this node). The three species of Potamonemus (P. mambilorum, P. man sp. nov., and $P$. sachsi) form an independent lineage within the subfamily Potamonautinae, and all are found in the same geographical area of Cameroon. The uncorrected p-distance between Potamonemus man sp. nov. and P. mambilorum is $2.2 \%$ for $12 \mathrm{~S}$ RNA and $0.6 \%$ for $16 \mathrm{RNA}$, and between $P$. man sp. nov. and $P$. sachsi it is $4.5 \%$ for $12 S$ RNA and $4.6 \%$ for $16 S$ RNA. 


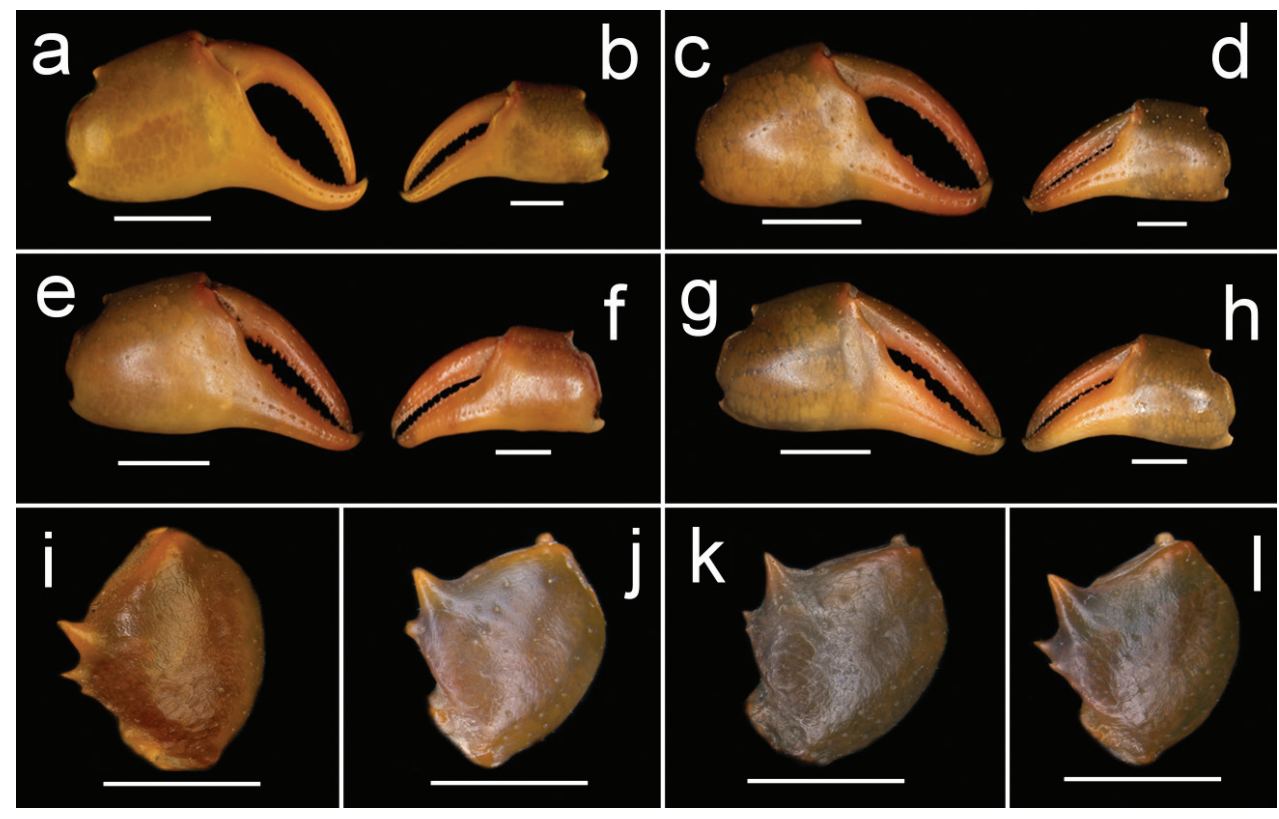

Figure 5. Frontal view of the right and left chelae of adult males of species of Potamonemus from southwestern Cameroon a, b largest adult male (CW $29 \mathrm{~mm}$ ) of P. mambilorum from Mount Nlonako (ZMB Crust. 32428) c, d adult male (CW $28 \mathrm{~mm}$ ) of P. mambilorum from small stream on Mount Manengouba (ZMB Crust. 30326) e, f largest adult male, holotype (CW $31 \mathrm{~mm}$ ) of $P$. man sp. nov. from Bakossi National Park (ZMB Crust. 30328) $\mathbf{g}$, h adult male, holotype (CW $25 \mathrm{~mm}$ ) of $P$. man sp. nov. from Man Lake, Mount Manengouba (ZMB Crust. 30320). Dorsal view of the right cheliped carpus of adult males of species of Potamonemus i, largest adult male (CW $29 \mathrm{~mm})$ of $P$. mambilorum from Mount Nlonako (ZMB Crust. 32428) j adult male (CW $28 \mathrm{~mm}$ ) of $P$. mambilorum from small stream on Mount Manengouba (ZMB Crust. 30326) $\mathbf{k}$ adult male (CW $31 \mathrm{~mm})$ of $P$. man sp. nov. from Bakossi National Park (ZMB Crust. 30328) I adult male, holotype (CW $25 \mathrm{~mm}$ ) of $P$. man sp. nov. from Man Lake, Mount Manengouba (ZMB Crust. 30320). Scale bars: $5 \mathrm{~mm}(\mathbf{a}, \mathbf{c}, \mathbf{g}), 2.5 \mathrm{~mm}(\mathbf{b}, \mathbf{d}, \mathbf{f}, \mathbf{h}), 5 \mathrm{~mm}(\mathbf{i}, \mathbf{j}, \mathbf{k}, \mathbf{I})$.

Conservation. Potamonemus man sp. nov. is found in an area of great conservation interest. The aquatic habitats of this species in the Mount Manengouba Ecological Reserve and in the Bakossi National Park are both in montane tropical rainforest in the Cameroon highlands, an area with a high biodiversity and a high rate of endemism, including freshwater crabs (Cumberlidge et al. 2019; Mvogo Ndongo et al. 2017a, d, c, 2018, 2019, 2020). In Mount Manengouba Ecological Reserve the small, forested stream near Man Lake where $P$. man sp. nov. lives also supports a sympatric population of the endangered freshwater crab Louisea balssi (Bott, 1959). Significantly, there are no reports of any species of invertebrates (molluscs, insects, crustaceans) or vertebrates (fish, amphibians, snakes, and birds) from Man Lake itself. This inhospitality to life may be related to the unusual green colour of its waters which may be due to the accumulation of lethal compounds, which may also be a potential danger to humans (see Mvogo Ndongo et al. 2018). Both the Mount Manengouba Ecological Reserve and the Bakossi National Park are under increasing pressure from growing nearby human populations 

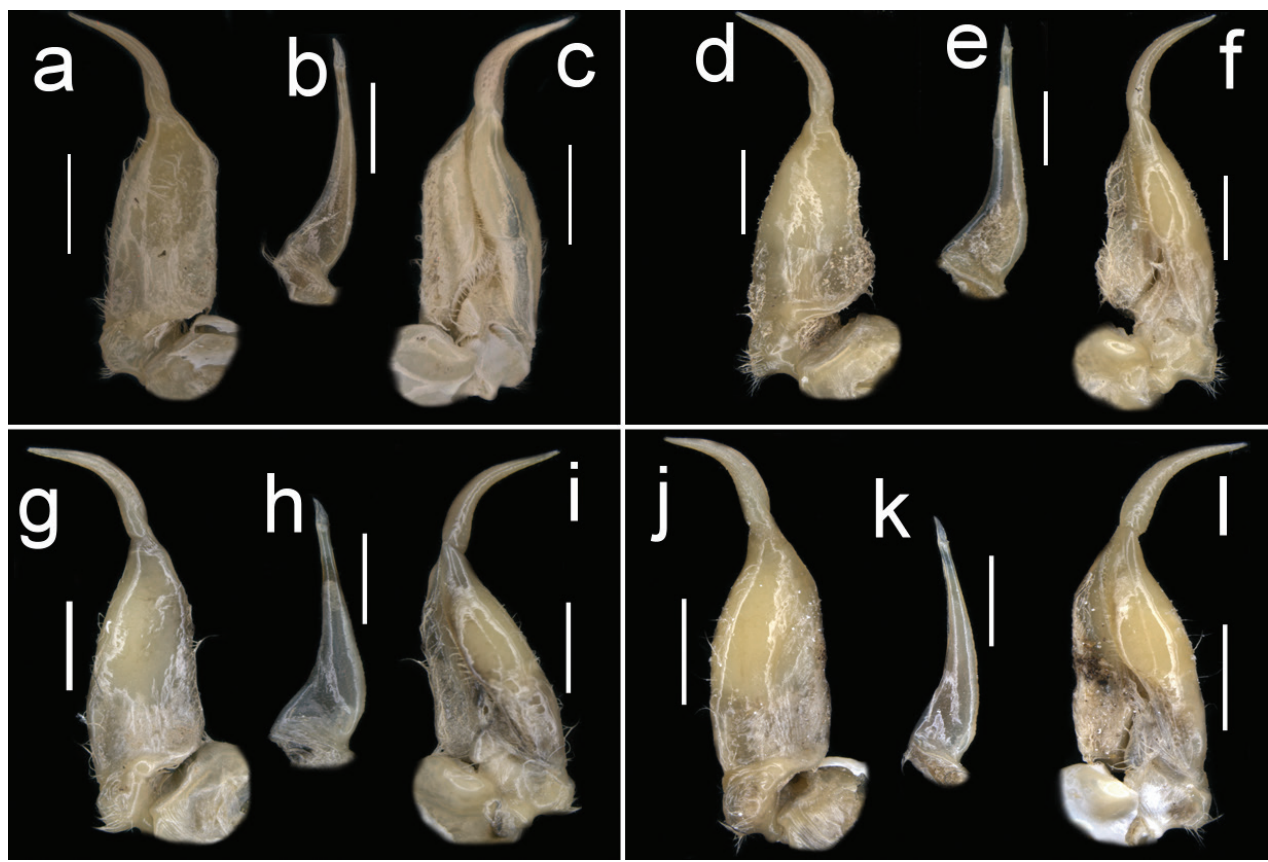

Figure 6. Dorsal view of left G1 (a, d, g, j) and ventral view of left G1 (c, $\mathbf{f}, \mathbf{i}, \mathbf{I})$ of adult males of species of Potamonemus from southwestern Cameroon. a, c largest adult male (CW $29 \mathrm{~mm}$ ) of $P$. mambilorum from Mount Nlonako (ZMB Crust. 32428) d, f adult male (CW $28 \mathrm{~mm}$ ) of P. mambilorum from small stream on Mount Manengouba (ZMB Crust. 30326) g, i adult male (CW $31 \mathrm{~mm}$ ) of $P$. man sp. nov. from Bakossi National Park (ZMB Crust. 30328) j, I adult male, holotype (CW $25 \mathrm{~mm}$ ) of $P$. man sp. nov. from Man Lake, Mount Manengouba (ZMB Crust. 30320). Ventral view of G2 of adult males of species of Potamonemus from southwestern Cameroon b largest adult male (CW $29 \mathrm{~mm}$ ) of P. mambilorum from Mount Nlonako (ZMB Crust. 32428) e adult male (CW $28 \mathrm{~mm})$ of $P$. mambilorum from small stream on Mount Manengouba (ZMB Crust. 30326) h adult male (CW $31 \mathrm{~mm}$ ) of $P$. man sp. nov. from Bakossi National Park (ZMB Crust. 30328) k adult male, holotype (CW $25 \mathrm{~mm}$ ) of $P$. man sp. nov. from Man Lake, Mount Manengouba (ZMB Crust. 30320). Scale bars: 2 mm (a-k).

and from the associated clearance of land for agriculture. As a result, despite being found in protected areas, the habitat of $P$. man sp. nov. is increasingly threatened by nearby intensive agricultural practices and forest destruction for firewood collection. In addition, the farmers encroaching on these habitats use agrochemicals and pesticides on their crops, and these pollutants eventually drain into the aquatic systems, potentially poisoning the freshwater communities (Mvogo Ndongo et al. 2018).

Potamonemus mambilorum Cumberlidge \& Clark, 1992

Figures 1b, 2b, 3b, 4b, 5c, d, i, 6d-f, 7b, f

Material examined. 6 adult $\widehat{\jmath}(\mathrm{CW} 29.05 \mathrm{~mm}$, CL $21.17 \mathrm{~mm}, \mathrm{CH} 12.10 \mathrm{~mm}$, FW 8.85 mm; CW 29.56 mm, CL 21.35 mm, CH 12.34 mm, FW 9.12 mm; 

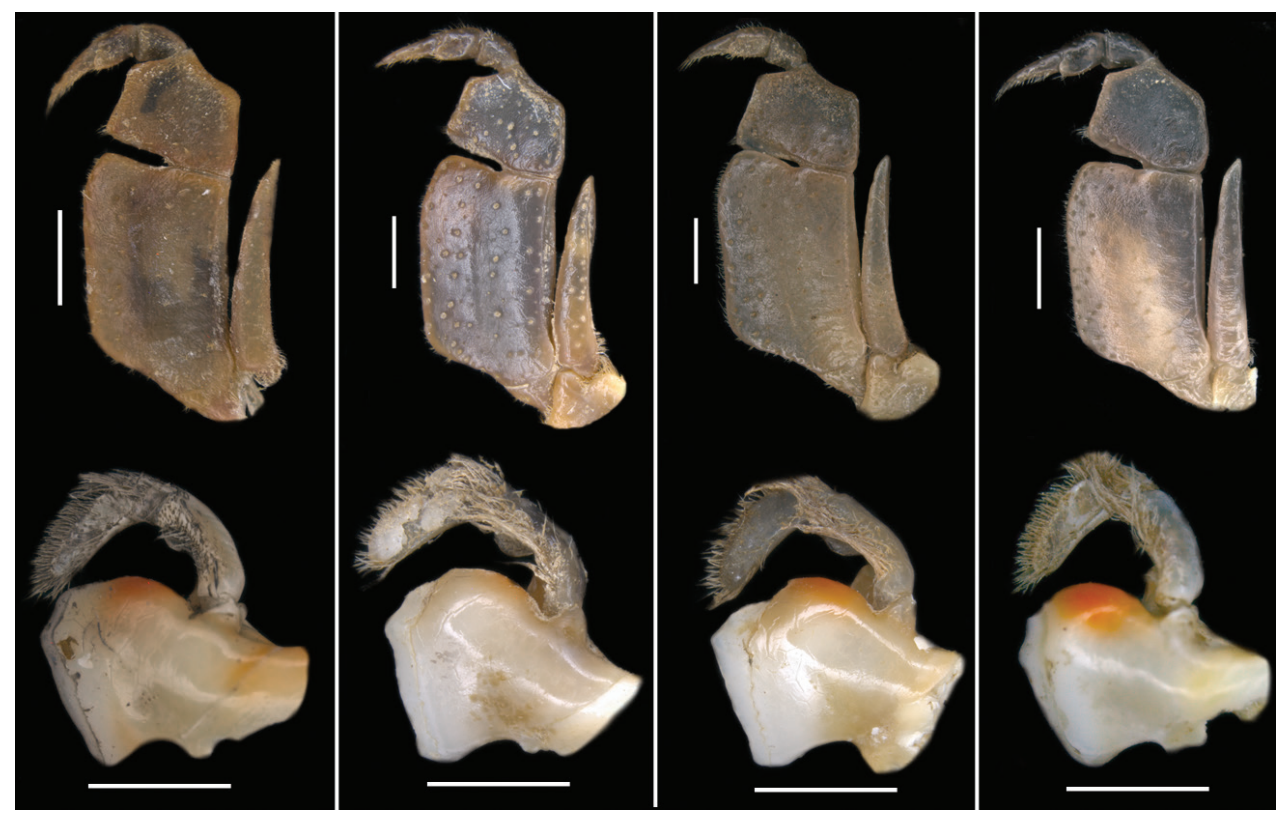

Figure 7. Frontal view of the left third maxilliped of adult males of species of Potamonemus from southwestern Cameroon a largest adult male (CW $29 \mathrm{~mm}$ ) of $P$. mambilorum from Mount Nlonako (ZMB Crust. 32428) b adult male (CW $28 \mathrm{~mm}$ ) of P. mambilorum from small stream on Mount Manengouba (ZMB Crust. 30326) c adult male (CW $31 \mathrm{~mm}$ ) of $P$. man sp. nov. from Bakossi National Park (ZMB Crust. 30328) d adult male, holotype (CW $25 \mathrm{~mm}$ ) of $P$. man sp. nov. from Man Lake, Mount Manengouba (ZMB Crust. 30320). Frontal view of the left mandible of adult males of species of Potamonemus from southwestern Cameroon e largest adult male (CW $29 \mathrm{~mm}$ ) of $P$. mambilorum from Mount Nlonako (ZMB Crust. 32428) fadult male (CW $28 \mathrm{~mm}$ ) of P. mambilorum from small stream on Mount Manengouba (ZMB Crust. 30326) $\mathbf{g}$ adult male (CW $31 \mathrm{~mm}$ ) of $P$. man sp. nov. from Bakossi National Park (ZMB Crust. 30328) h adult male, holotype (CW 25 mm) of $P$. man sp. nov. from Man Lake, Mount Manengouba (ZMB Crust. 30320). Scale bars: 5 mm (a-d), $2 \mathrm{~mm}(\mathbf{e}-\mathbf{h})$.

CW $29.16 \mathrm{~mm}$, CL $20.70 \mathrm{~mm}$, CH $12.00 \mathrm{~mm}$, FW $9.12 \mathrm{~mm}$; CW $28.93 \mathrm{~mm}$, CL 20.69 mm, CH 11.85 mm, FW 9.94 mm; CW 26.74 mm, CL $19.62 \mathrm{~mm}, \mathrm{CH}$ $11.32 \mathrm{~mm}$, FW $9.63 \mathrm{~mm}$; CW $26.74 \mathrm{~mm}$, CL $19.62 \mathrm{~mm}, \mathrm{CH} 11.32 \mathrm{~mm}$, FW $9.63 \mathrm{~mm}$ ). 2 adult + (CW $27.06 \mathrm{~mm}$, CL $19.76 \mathrm{~mm}, \mathrm{CH} 12.45 \mathrm{~mm}$, FW $8.34 \mathrm{~mm}$; CW $26.68 \mathrm{~mm}$, CL $19.06 \mathrm{~mm}$, CH $11.03 \mathrm{~mm}$, FW $7.72 \mathrm{~mm}$ ); Cameroon, Littoral region, Mount Nlonako Ecological Reserve (4.891820, 9.984830), $900 \mathrm{~m}$ a.s.l., 26 May 2018, coll. P.A. Mvogo Ndongo (ZMB Crust. 32428). 1 adult ô (CW $28.00 \mathrm{~mm}$, CL $19.10 \mathrm{~mm}, \mathrm{CH} 11.37 \mathrm{~mm}, \mathrm{FW} 8.56 \mathrm{~mm}$ ); 1 adult ( (CW $28.36 \mathrm{~mm}$, CL $20.00 \mathrm{~mm}$, CH 10.27 mm, FW 7.79 mm; Southwest Region, Mount Manengouba Ecological Reserve, small stream around the mountain (ZMB Crust. 30326) (5.034920, 9.836150), 1,958 m asl, 14 March 2017, coll. P.A. Mvogo Ndongo.

Remarks. The distributional range of $P$. mambilorum is extended in this work by the discovery of populations in Mount Nlonako Ecological Reserve in the littoral region of Cameroon. Potamonemus mambilorum was previously known from seven localities in 


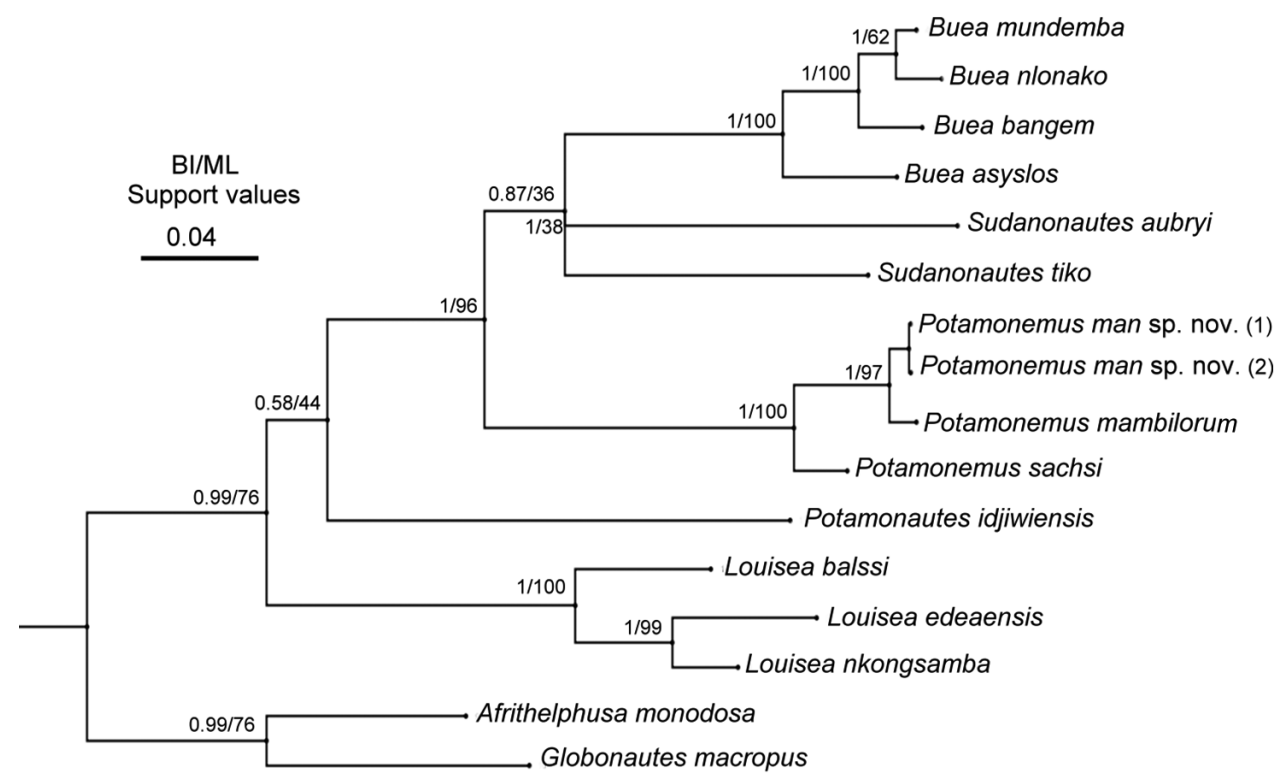

Figure 8. Bayesian Inference (BI) tree topology for the freshwater crab taxa from Cameroon included in this study derived from mtDNA sequences corresponding to three loci (partial $16 \mathrm{~S}$ rRNA, COI, and $12 \mathrm{~S}$ rRNA genes). Bayesian Inference (BI) and ML statistical values (\%) on the nodes indicate bootstrap support and posterior probabilities, respectively.

the forested highlands and lowlands of southwestern Cameroon (extent of occurrence (EOO) $43,291 \mathrm{~km}^{2}$ ). The conservation status of this species was assessed as Least Concern (Cumberlidge 2008a), but this was before the threats to the freshwater ecosystems of this part of Africa were brought to light. The conservation status of $P$. sachsi was assessed as Vulnerable, B1ab(iii)+2ab(iii), based on its distributional range that includes the Bamenda highlands in southwest Cameroon and the neighboring Obudu plateau in southeast Nigeria, which is continuous with the Bamenda highlands (EOO 24,219 $\mathrm{km}^{2}$ ) and perceived threats (Cumberlidge 2008b). The areas where P. mambilorum and P. sachsi occur are now known to be at risk from a number of anthropogenic threats, including deforestation, together with intensive and encroaching agricultural practices and firewood collection, as well as release of pollutants such as agrochemicals potentially affecting the eggs, hatchling-carrying female crabs, and other aquatic organisms.

\section{Key to the species of Potamonemus Cumberlidge \& Clark, 1992}

1 Dactylus of major cheliped highly arched (Fig. 5a) P. mambilorum

- Dactylus of major cheliped either straight or only slightly concave. .2

2 Carapace sidewalls in subhepatic and pterygostomial regions smooth

- $\quad$ Carapace sidewalls in subhepatic and pterygostomial regions with fields of short setae (Cumberlidge 1994: figs 3a, 4c). 


\section{Acknowledgements}

We thank the Rufford Small Grant Foundation for funding the fieldwork in the South and Southwestern Regions of Cameroon, and the Museum für Naturkunde, Berlin (ZMB) for funding the first author during a research visit to Germany. We thank Dr. Paul F. Clark (Natural History Museum, London, UK) and Prof. Dr Christoph D. Schubart (University of Regensburg, Germany) for constructive comments in the earlier manuscript. Thanks are also due to the two anonymous reviewers and the Subject Editor for their important comments to improve the manuscript.

\section{References}

Cumberlidge N (1987) Notes on the taxonomy of West African gecarcinucids of the genus Globonautes (Brachyura, Decapoda). Canadian Journal of Zoology 65: 2210-2215. https:// doi.org/10.1139/z87-335

Cumberlidge N (1989) Redescription of Sudanonautes orthostylis Bott, 1955, a freshwater crab from Nigeria, Cameroon and Ghana with notes on its ecology (Decapoda, Potamonautidae). Crustaceana 56: 230-245. https://doi.org/10.1163/156854089X00220

Cumberlidge N (1993a) Redescription of Sudanonautes granulatus (Balss, 1929) (Potamoidea, Potamonautidae) from West Africa. Journal of Crustacean Biology 113: 805-816. https:// doi.org/10.2307/1549111

Cumberlidge N (1993b) Further remarks on the identification of Sudanonautes orthostylis (Bott, 1955) with comparisons with other species from Nigeria and Cameroon. Proceedings of the Biological Society of Washington 106: 514-522.

Cumberlidge N (1993c) Two new species of Potamonemus Cumberlidge and Clark, 1992 (Brachyura, Potamoidea, Potamonautidae) from the rain forests of West Africa. Journal of Crustacean Biology 13: 571-584. https://doi.org/10.2307/1548798

Cumberlidge, N. (1994a) Identification of Sudanonautes aubryi (H. Milne-Edwards, 1853) (Brachyura: Potamoidea: Potamonautidae) from West and Central Africa. Zeitschrift für Angewandte Zoologie 80: 225-241

Cumberlidge N (1994b) Louisea, a new genus of freshwater crab (Brachyura: Potamoidea: Potamonautidae) for Globonautes macropus edeaensis Bott, 1969 from Cameroon. Proceedings of the Biological Society of Washington 107: 122-131.

Cumberlidge N (1999) The Freshwater Crabs of West Africa, Family Potamonautidae. Faune et Flore tropicales 35. Institut de Recherche pour le Développement, Paris, 382 pp.

Cumberlidge N (2008a) Louisea edeaensis. The IUCN Red List of Threatened Species 2008: e.T12383A3339062. https://doi.org/10.2305/IUCN.UK.2008.RLTS.T12383A3339062.en

Cumberlidge N (2008b) Louisea balssi. The IUCN Red List of Threatened Species 2008: e.T134759A4009175. https://doi.org/10.2305/IUCN.UK.2008.RLTS. T134759A4009175.en

Cumberlidge N, Boyko CB (2001) Freshwater crabs (Brachyura: Potamoidea: Potamonautidae) from the rainforests of the Central African Republic. Proceedings of the Biological Society of Washington 3: 406-419. 
Cumberlidge N, Clark PF (1992) A new genus and species of fresh-water crab from Cameroon, West Africa (Crustacea, Brachyura, Potamoidea, Potamonautidae). Bulletin of the British Museum (Natural History) 58: 149-156.

Cumberlidge N, Mvogo Ndongo PA, Clark PF, Daniels SR (2019) A new genus for the freshwater crab Potamonemus asylos Cumberlidge, 1993, (Brachyura: Potamoidea: Potamonautidae) from Cameroon, Central Africa, with a key to the genera of the Potamonautinae. Journal of Natural History 53: 659-676. https://doi.org/10.1080/00222933.2019.1583390

Daniels SR, Cumberlidge N, Pérez-Losada M, Marijnissen SAE, Crandall KA (2006) Evolution of Afrotropical freshwater crab lineages obscured by morphological convergence. Molecular Phylogenetics and Evolution 40: 227-235. https://doi.org/10.1016/j.ympev.2006.02.022

Daniels SR, Phiri EE, Klaus S, Albrecht C, Cumberlidge N (2015) Multi-locus phylogeny of the Afrotropical freshwater crab fauna reveals historical drainage connectivity and transoceanic dispersal since the Eocene. Systematic Biology 64: 549-567. https://doi.org/10.1093/sysbio/syv011

Kusakabe M (2017) Lakes Nyos and Monoun gas disasters (Cameroon) - Limnic eruptions caused by excessive accumulation of magmatic $\mathrm{CO}_{2}$ in crater lakes. Geochemistry, Monograph, Series 1: 1-50. https://doi.org/10.5047/gems.2017.00101.0001

Mvogo Ndongo PA, von Rintelen T, Cumberlidge N (2019) Taxonomic revision of the endemic Cameroonian freshwater crab genus Louisea Cumberlidge, 1994 (Crustacea, Decapoda, Brachyura, Potamonautidae), with descriptions of two new species from Nkongsamba and Yabassi. ZooKeys 881: 135-164. https://doi.org/10.3897/zookeys.881.36744

Mvogo Ndongo PA, von Rintelen T, Tomedi-Tabi Eyango M, Cumberlidge N (2020) Morphological and molecular analyses reveal three new species of the freshwater crab genus Buea Cumberlidge, Mvogo Ndongo, Clark \& Daniels, 2019 (Crustacea: Brachyura: Potamonautidae) from a rainforest biodiversity hotspot in Cameroon, Central Africa. Journal of Crustacean Biology 40: 288-300. https://doi.org/10.1093/jcbiol/ruaa019

Mvogo Ndongo PA, Schubart CD, von Rintelen T, Tamesse JL, Cumberlidge N (2017a) Morphological and molecular evidence for a new species of freshwater crab of the genus Sudanonautes Bott, 1955 (Brachyura: Potamoidea: Potamonautidae) from Cameroon, with notes on its ecology. Zootaxa 4242: 161-173. https://doi.org/10.11646/zootaxa.4242.1.8 Mvogo Ndongo PA, von Rintelen T, Albrecht C, Tamesse JL, Cumberlidge N (2018) Lost species in Cameroon: rediscovery of the endangered freshwater crab, Louisea balssi (Bott, 1959) (Brachyura: Potamonautidae), with notes on its ecology and conservation. Zootaxa 4394: 407-416. https://doi.org/10.11646/zootaxa.4394.3.6

Mvogo Ndongo PA, von Rintelen T, Schubart CD, Albrecht C, Tamesse JL, Cumberlidge N (2017b) New data on the taxonomy, ecology, and conservation of the rediscovered Louisea edeaensis (Bott, 1969) (Brachyura: Potamoidea: Potamonautidae), an endangered freshwater crab from Cameroon. Zootaxa 4231: 273-280. https://doi.org/10.11646/zootaxa.4231.2.9

Mvogo Ndongo PA, Cumberlidge N, Poettinger TS, von Rintelen T, Tamesse JL, Schubart CD (2017c) Molecular evidence for the assignment of the Cameroonian freshwater crab genus Louisea Cumberlidge, 1994, to the Afrotropical subfamily Potamonautinae Bott, 1970 (Crustacea: Potamoidea: Potamonautidae). Zootaxa 4286: 439-444. https://doi.org/10.11646/ zootaxa.4286.3.12

Ng PKL, Guinot D, Davie PJF (2008) Systema Brachyuorum: part I. An annotated checklist of extant Brachyuran crabs of the world. Raffles Bulletin of Zoology Supplement 17: 1-286. 